\title{
Ai trồng cây, em trồng cây
}

Khúc Văn Quý

HN, 6-3-2022

Preprint DOI: https://osf.io/ysbv9

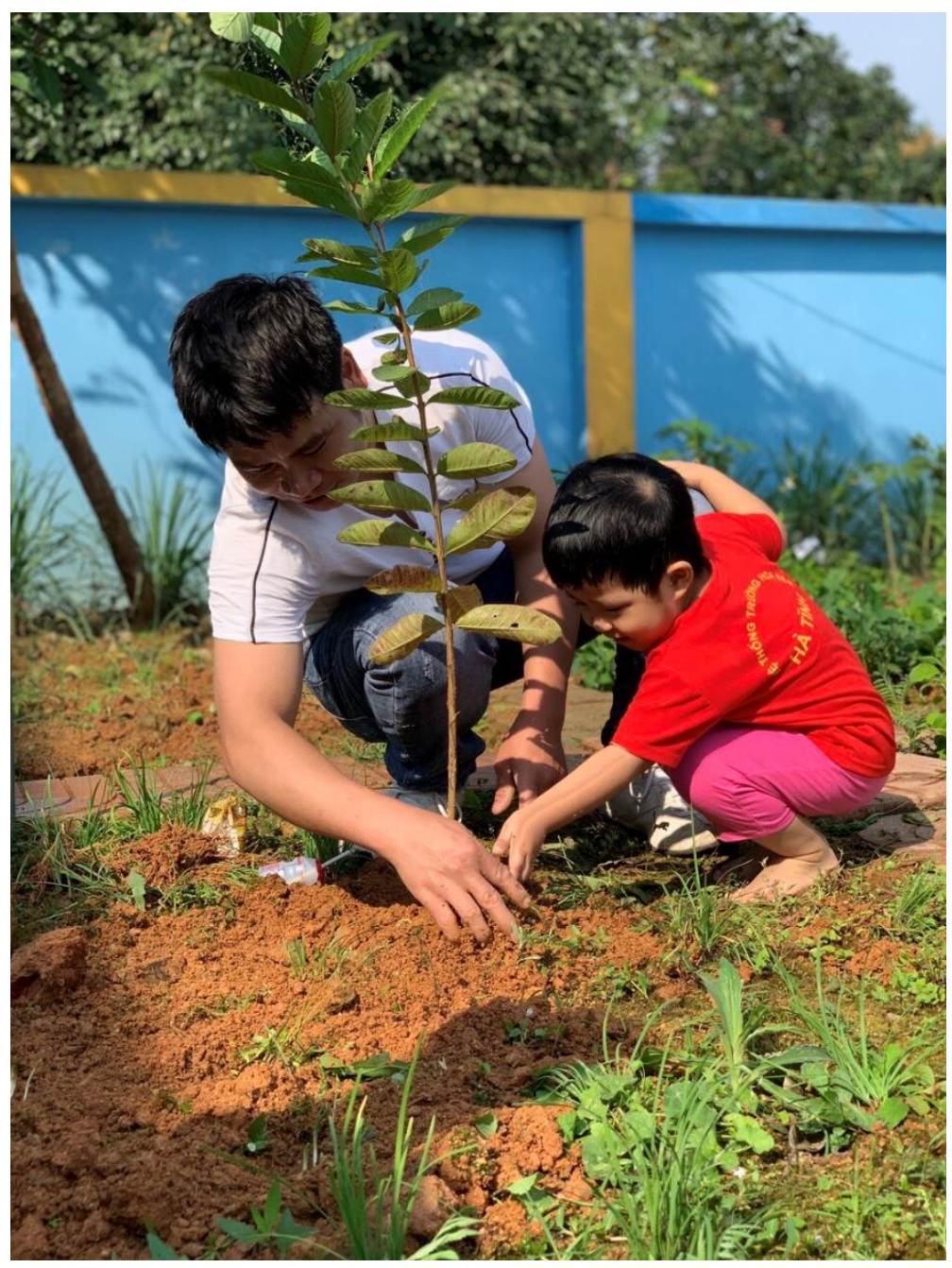

Hình 1. Ai trồng cây, em trồng cây

Source: https://hbe.edu.vn/ngay-hoi-tet-tron-cay-2019 


\section{Tài liệu tham khảo}

Khuc, Q. V. et al. (2020). Forest cover change, households' livelihoods, trade-offs, and constraints associated with plantation forests in poor upland-rural landscapes: Evidence from north central Vietnam. Forests, 11(5). https://doi.org/10.3390/F11050548

Khuc, Q. V. et al. (2021). Understanding Vietnamese Farmers' Perception toward Forest Importance and Perceived Willingness-to-Participate in REDD + Program: A Case Study in Nghe An Province. Forests, 12, 521. https://doi.org/10.3390/f12050521

Khuc, Q Van. (2021). Khucc tower: from cultural values to practical solutions. OSF Preprints. https://doi.org/10.31219/osf.io/stbj4

Khuc, Quy Van. (2021). Environmental culture thoughts to make a better world for our nature and children. OSF Preprints. https://doi.org/10.31219/osf.io/g5zex

Khuc, Quy Van. (2022a). "Tết” và tính cộng văn hóa dân tộc - môi trường. Kinh Tế và Dự Báo. https://kinhtevadubao.vn/tet-va-tinh-cong-van-hoa-dan-toc-moi-truong-21261.html

Khuc, Quy Van. (2022b). Về khả năng ứng dụng của hệ xử lý thông tin 3D và nguyên lý bán dẫn giá trị trong tìm kiếm giải pháp cho vấn đề ô nhiễm môi trường và biến đổi khí hậu ở Việt Nam. Kinh Tế và Dự Báo. https://kinhtevadubao.vn/ve-kha-nang-ung-dung-cua-he-xu-ly-thong-tin-3d-va-nguyenly-ban-dan-gia-tri-trong-tim-kiem-giai-phap-cho-van-de-o-nhiem-moi-truong-va-bien-doi-khi-hauo-viet-nam-20840.html

Khuc, Quy Van, Alhassan, M., Loomis, J., Trung, T., \& Paschke, M. (2016). Estimating Urban Households' Willingness-to-Pay for Upland Forest Restoration in Vietnam. Open Journal of Forestry, 06(03), 191-198. https://doi.org/10.4236/ojf.2016.63016

Khuc, Quy Van, Nguyen, M.-H., Le, T.-T., Nguyen, T., \& Vuong, Q.-H. (2021). Brain drain out of the blue: pollution-induced migration in a developing country. OSF Preprints. https://doi.org/10.31219/osf.io/rn2qe

Khuc, Quy Van, Nong, D., \& Phu, T. V. (2020). Willingness-to-pay for reducing air pollution in the world'most dynamic cities: Evidence from Hanoi, Vietnam. Working Paper.

Khuc, Quy Van, Phu, T. V., \& Luu, P. (2020). Dataset on the Hanoian suburbanites' perception and mitigation strategies towards air pollution. Data in Brief, 33, 106414. https://doi.org/10.1016/j.dib.2020.106414

Khuc, Quy Van, Tran, B. Q., Meyfroidt, P., \& Paschke, M. W. (2018). Drivers of deforestation and forest degradation in Vietnam: An exploratory analysis at the national level. Forest Policy and Economics, 90(June 2017), 128-141. https://doi.org/10.1016/j.forpol.2018.02.004

Khuc, Quy Van, \& Vuong, Q.-H. (2020). Environmental cultural value and global environmental change: By nature, of nature, for nature. OSF Preprints. https://doi.org/10.31219/osf.io/xzsjg

Magliocca, N., Khuc, Q. Van, Bremond, A. de, \& Ellicott, E. (2019). Archetypical pathways of direct and indirect land-use change caused by Cambodia's economic land concessions. Ecology and Society, 24(2). https://doi.org/10.5751/ES-10954-240225

Magliocca, N. R., Khuc, Q. Van, De Bremond, A., \& Ellicott, E. A. (2020). Direct and indirect land-use change caused by large-scale land acquisitions in Cambodia. Environmental Research Letters, 15(2). https://doi.org/10.1088/1748-9326/ab6397

Nguyen, M. (2021). Building an eco-surplus culture is a possible solution for curbing environmental problems. OSF Preprints, November. https://doi.org/10.31219/osf.io/qa9dx

Nguyen, M. H., Le, T. T., Nguyen, H. K. T., Ho, M. T., Thanh Nguyen, H. T., \& Vuong, Q. H. (2021). 
Alice in suicideland: Exploring the suicidal ideation mechanism through the sense of connectedness and help-seeking behaviors. International Journal of Environmental Research and Public Health, 18(7), 1-24. https://doi.org/10.3390/ijerph18073681

Nguyen, M. H., \& Vuong, Q. H. (2021). Evaluation of the Aichi Biodiversity Targets: The international collaboration trilemma in interdisciplinary research. Pacific Conservation Biology. https://doi.org/10.1071/PC21026

Quan-Hoang Vuong, Le, T.-T., Khuc, Q., \& Nguyen, M.-H. (2022). A new theory of serendipity. In: QH Vuong. (Ed.) A New Theory of Serendipity: Nature, Emergence and Mechanism(pp. 91-108). Berlin, Germany: De Gruyter.

Vuong, Q.-H. (2021). Western monopoly of climate science is creating an eco-deficit culture. Economy, Land \& Climate Insight. https://ssrn.com/abstract=3961624

Vuong, Q. (2020). From children's literature to sustainability science, and young scientists for a more sustainable Earth From children's literature to sustainability science, and young scientists for a more sustainable Earth. Journal of Sustainability Education, 24(December), 2019-2021.

Vuong, Q. H. (2018). The (ir)rational consideration of the cost of science in transition economies. Nature Human Behaviour, 2(1), 5. https://doi.org/10.1038/s41562-017-0281-4

Vuong, Q. H. (2021). The semiconducting principle of monetary and environmental values exchange. Economics and Business Letters, 10(3), 284-290. https://doi.org/10.17811/ebl.10.3.2021.284-290

Vuong, Q. H. et al. (2020). Identifying the moral-practical gaps in corporate social responsibility missions of Vietnamese firms: an event-based analysis of sustainability feasibility. Corporate Social Responsibility Environment Management, April, 1-12. https://doi.org/10.31219/osf.io/mcdq4

Vuong, Q. H. et al. (2021a). Escaping from air pollution: The psychological process of domestic migration intention among urban people. ArXiv.

Vuong, Q. H. et al. (2021b). Exploring Inner-City Residents' and Foreigners' Commitment to Improving Air Pollution: Evidence from a Field Survey in Hanoi, Vietnam. Data, 6(39). https://doi.org/10.3390/data6040039

Vuong, Q. H. et al. (2021c). On the environment-destructive probabilistic trends: A perceptual and behavioral study on video game players. Technology in Society, 65(January), 101530. https://doi.org/10.1016/j.techsoc.2021.101530

Vuong, Q. H. et al. (2022). Covid-19 vaccines production and societal immunization under the serendipity-mindsponge-3D knowledge management theory and conceptual framework. Humanities and Social Sciences Communications, 9(1), 1-12. https://doi.org/10.1057/s41599-022-01034-6

Vuong, Q. H., Ho, M. T., Nguyen, H. K. T., \& Nguyen, M. H. (2019). The trilemma of sustainable industrial growth: evidence from a piloting OECD's Green city. Palgrave Communications, 5(1), 114. https://doi.org/10.1057/s41599-019-0369-8

Vuong, Q. H., \& Napier, N. K. (2014). Making creativity: the value of multiple filters in the innovation process. International Journal of Transitions and Innovation Systems, 3(4). https://doi.org/10.1504/IJTIS.2014.068306

Vuong, Q. H., \& Napier, N. K. (2015). Acculturation and global mindsponge: An emerging market perspective. International Journal of Intercultural Relations, 49, 354-367. https://doi.org/10.1016/j.ijintrel.2015.06.003 